\title{
1974 KIBRIS HAVA HAREKÂTI
}

\section{Davud KAPUCU*}

\section{Özet}

Kıbrıs, tarihi süreç içerisinde birçok devlet ve toplumun egemenliği altına girmiştir. Bu süreçte 1571 yllında Osmanlı egemenliği altına giren ada, 1878 Ayastefanos Antlaşmasının değiştirilmesi karşılığında İngiltere'nin yönetimine bırakılmıştır.

Birinci Dünya Savaşı sırasında karşıt cephede yer alan İngiltere, Kıbrıs adasını topraklarına kattığını açıklamıştır. Osmanlı devleti bu durumu protesto etmiş ancak herhangi bir müdahalede bulunamamıştır.

İstiklal Harbi sonrasında imza edilen Lozan Antlaşması ile yeni kurulan Türkiye Devleti Ada'nın İngiltere'nin mülkü olduğunu kabul etmiştir. İkinci dünya savaşı sonrasında meydana gelen siyasal ortamda adadaki Rumların enosis hedefi ile Yunanistan'a bağlanmak istemesi çatışmaların temelini oluşturmuştur. Neticede 1960 yılında başlayan uluslararası görüşmeler sonucunda Türkiye, İngiltere ve Yunanistan'ın garantör olduğu adadaki Türk ve Rumlar tarafından ortak Kıbrıs Cumhuriyeti kurulmuştur. Ortak Kıbrıs Cumhuriyeti'ne karşı Ada'daki Rumların enosis eksenli faaliyetleri önce 1964 Kıbrıs Hava Harekâtının düzenlenmesine neden olmuştur. Ardından gelişen evrede Rumların hedef ve ideallerinden vazgeçmemesi 1974 Kıbrıs Barış Harekatı'nın yapılmasına etki etmiştir.

Bu çalışmada 1974 Kıbrıs Barış Harekâtı sırasında icra edilen hava harekâtına ve havacıların rolüne yer verilecektir.

Anahtar Kelimeler: Kıbrıs, Savaş, Barış, Harekât, Uçak.

\section{CYPRUS AIR OPERATION}

\section{Abstract}

Cyprus had been under the sovereignty of many states and societies throughout its history. In this process, the island, which came under the Ottoman rule in 1571, was left to the administration of England against for the amendment of the 1878 Ayastefanos Treaty.

During the First World War, Britain, which was on the opposite front, announced that it had annexed the island of Cyprus to its territory. The Ottoman state had protested this situation but could not intervene.

Government of Turkiye, which had been established newly by signed the Treaty of Lausanne after indepence war, accepted the island as the property of Britain. In the political environment that occurred after the Second World War, the Greek Cypriots on the island wanted to join Greece with the goal of Enosis formed the basis of the conflicts. As a result of international negotiations began in 1960, Turkey, Britain and Greece on the island where being as guarantor was established The Common Republic of Cyprus by the Greek Cypriots and Turks. The Enosis-oriented activities of the Greeks on the island against the Common Cyprus Republic first led to the organization of the 1964 Cyprus Air Operation. In the following stage, because of fact that the Greeks had not gave up their goals and ideals and it was affected the Cyprus Peace Operation of 1974.

\footnotetext{
*Dr., Ankara, dkapucu@hotmail.com
} 
In this study, the air operation during the 1974 Cyprus Peace Operation and the role of airmen will be mentioned.

KeyWords: Aircraft, Cyprus, Operation, Peace, War

\section{Giriş}

Kıbrıs, dünyanın doğusu ile batısı ve kuzeyi ile güneyi arasındaki stratejik konumu, iklimi, ticaret yolları üzerindeki yeri sebebiyle tarihsel süreç içerisinde birçok toplumun egemenliği altında kalmıştır.

1571 yılında Osmanlı hâkimiyeti altına giren Kıbrıs yaklaşık 300 yıldan fazla bir süre Türk adası olarak anılmıştır. Kıbrıs'ın ele geçirilmesinden sonra Osmanlı Devleti, adanın Türkleşmesi ve bölgenin güvenliğinin sağlanması için buraya Karaman, Konya ve Mersin taraflarından önemli bir Türk nüfus iskân etmiş̧tir. Bu sırada Ada'da yer alan Rum nüfus ile Türkler Osmanlı egemenliği altında barış ve huzur içerisinde yaşamlarını devam ettirmiştir.

Osmanlı Devleti'nin 1877-1878 Rus harbi sonrasında imza ettiği Ayastefanos Antlaşması ile ülke zor şartlar altında kalmıştır. Bu durumdan faydalanan İngiltere'nin Ayastefanos Antlaşması'nın değiştirilmesi konusunda vereceği destek karşılığında Kıbrıs, Büyük Britanya Krallığı'na (şartlı olarak) devredilmiştir. Böylece Ada'nın mülkiyeti Osmanlı'da kalmış ancak yönetimi İngiltere'ye verilmiştir. ${ }^{1}$ Birinci Dünya Savaşı sırasında İngiltere, Kıbrıs'1 topraklarına kattı̆̆ını duyurmuştur. Osmanlı bu kararı protesto etmiş ancak herhangi bir müdahale girişiminde bulunamamıştır.

Birinci Dünya Savaşı'ndan sonra Mondros Mütarekesi'ne dayanılarak Anadolu'nun işgali üzerine milli mücadele başlamıştır. ${ }^{2}$ İstiklal Harbi sonrasında İtilaf güçleri ile yeni kurulan Türkiye Devleti arasında Lozan Antlaşması imzalanmıştır. ${ }^{3} \mathrm{Bu}$ antlaşma ile Türkiye, Kıbrıs'ın İngiltere'nin mülkiyetine girdiğini kabul etmiştir. Böylece (Kıbrıs) Ada tam anlamı ile İngiltere egemenliğine girmiştir. ${ }^{4}$ Rumlar, Ada'nın İngiltere'de olduğu dönemlerin ilk yıllarından itibaren burasının kendilerine ait olması yönünde faaliyete başlamıştır. Şüphesiz Rumların her zaman destek gördüğü ülke öncelikle Yunanistan olmuştur.

\footnotetext{
${ }^{1}$ Kenan Olgun-Emrah Balıkçıŏlu, “The Times Gazetesi'ne Göre İngiliz Dönemindeki Kıbrıs'ta İdari Islahat", Uluslararası Insan Bilimleri Dergisi, Cilt: 9, Sayı: 1, 2012, s.816-844.

2 Erdal Korkmaz, "TBMM Zabıt Cerideleri Nutuk Ekseninde Saltanatın Kaldırılması”, Sosyal ve Beşeri Bilimlere Multidisipliner Bakış, Editörler: Ayhan Aytaç, Giray Saynur Derman, Mustafa Talas, Güven Plus Grup A.Ş. Yayınları, İstanbul, 2019, s.119.

${ }^{3}$ Davud Kapucu, Erdal Korkmaz, Osmanli'dan Cumhuriyete Askeri Hava Seyahatleri, Karakum Yayınevi, Ankara, 2020, s.77-78.

${ }^{4}$ Büşra Çakmak, "Kıbrıs'ta İngiliz Yönetimi ve Yapılan Çözüm Planları", Tarihte Kıbrıs II, Editör: Osman Köse, Akdeniz Karpaz Üniversitesi, İstanbul, 2017, s.860.
} 
İkinci Dünya Savaşı'ndan sonra Ada'daki Rumların enosis adı verilen Yunanistan ile birleşmeye dönük faaliyetleri adadaki barış ortamını bozmuştur. Bu sırada İngiltere Ada'dan çekilmeye karar vermiştir. İngiltere'nin bölgeden çekilme yönündeki kararı, Kıbrıs'taki Rumların enosis çaba ve girişimlerini artırmalarına neden olmuştur. Türkiye ilk başlarda Yunanistan ile olan iyi ilişkileri sebebiyle gelişmelere uzak kalmış olmakla birlikte Kıbrıs'ta Türklere yönelik olumsuz gelişmeler ve Türkiye'nin Doğu Akdeniz'den kuşatılması gerçeği karşısında politik duruşunu değiştirmiştir. Bu gelişmeler üzerine Türkiye'nin girişimi ile yapılan görüşmeler sonucunda 1959 ve 1960 yıllarında imzalanan Londra ve Zürih Antlaşmaları ile Ada'daki Türk ve Rumların ortaklığında bir Kıbrıs Devleti kurulmuştur. ${ }^{5}$ Ayrıca ilgili antlaşmalara istinaden Türkiye, İngiltere ve Yunanistan Kıbrıs için garantör devlet olmuşlardır. Yapılan antlaşma ile Ada'daki Cumhurbaşkanlığı makamının Rum, Cumhurbaşkanı yardımcısının ise Türk olması kararlaştırılmıştır. Londra ve Zürih Antlaşmaları sonucunda yapılan cumhurbaşkanlığı seçimlerini Başpiskopos Makarios, cumhurbaşkanlığı yardımcılığını ise Doktor Fazıl Küçük kazanmıştır. ${ }^{6}$

Meşru seçimler sonucunda oluşturulan statüye karşı adadaki Rumların enosise yönelik adımları ve Türklerin katledilmesi üzerine 7-9 Ağustos 1964 tarihlerinde Türkiye tarafından Kıbrıs'a yönelik hava harekâtı düzenlenmiştir. ${ }^{7}$ Bu hava harekâtı sonrasında uluslararası toplumun araya girmesi ile çatışmalar durdurulmuştur.

Ada'daki Rumların saldırıları ile zaman zaman tansiyonun yükseldiği Kıbrıs'ta 1974 yılında Türklerin katledilmesi ve Cumhurbaşkanı Makarios'a yönelik darbe girişimi Türkiye'nin garantör ülke olarak müdahalesini gündeme getirmiştir. ${ }^{8}$

\section{Harekâtın Sebepleri}

Türkiye'nin 1964 Kıbrıs Hava Harekâtı sonrası, ABD ve NATO ile ilişkilerinde gerilemeler meydana gelmiştir. Türk Dışişleri Bakanı ile Sovyet Başkanının 1965'te karşılıklı ziyaretleri sonunda iki devlet arasında bir yaklaşma başlamıştır. Ancak Ruslar o dönemde Kıbrıs konusunda Türk tarafından yana tavır sergilememiştir. Bu dönemde Türkiye, hem Birleşmiş

\footnotetext{
${ }^{5}$ Turgut Turhan; "Tarihsel Bakış Açısıyla Kıbrıs Türk Hukuk Sistemi”, Ankara Üniversitesi Hukuk Fakültesi Dergisi, Ankara-2008, C. 57, S. 2, s.253-286.

${ }^{6}$ Müge Atasever, Kıbrıs Sorununun Tarihi Gelişimi, Dokuz Eylül Üniversitesi Hukuk Fakültesi Dergisi, Cilt: 12, Özel S., 2010, s.1487-1530 (Basım Yıl1: 2012).

${ }^{7}$ Ali Denizli, “Kıbrıs'ta Kanlı Noel-1963 Yunan ve Rum İkilisince Türk Halkının Yok Edilmeye Çalışılması", Prof. Dr. Abdulhalûk Mehmet Çay 35. Yıl Armağan Kitabı, İksad Yayınevi, Ankara, 2020, s.157-158.

${ }^{8}$ Hamza Eroğlu; Kıbrıs Uyuşmazlı̆̆ı ve Kıbrıs Barış Harekâtı, Ankara, 1975, s.58.
} 
Milletler içindeki nüfuzunu artırmak hem de Bağlantısızlara ve Üçüncü Dünyaya yaklaşmak istemiş olmasına rağmen istediği sonucu elde edememiştir. Birleşmiş Milletler Güvenlik Konseyi Genel Sekreteri Sakari Tuomioja'nın 9 Eylül 1964'te ölümünün ardından yerine göreve başlayan Ekvator'lu diplomat Galo Plaza Lasso, Makarios'un isteklerini aynen kabullenerek, Kıbrıs Türk toplumunu azınlık konumuna düşürmeyi ve Ada'nın askerden arındırılmasını isteyerek, Garanti Anlaşmasını ortadan kaldırma niyetiyle 26 Mart 1965'te Genel Sekretere bir rapor vermiştir. ${ }^{9}$ Türkiye, Lasso'nun sunmuş olduğu raporu, uluslararası hukuka aykırı olduğu gerekçeleriyle doğrudan reddetmiştir. ${ }^{10}$ Türkiye'nin aksine Yunanistan ve Kıbrıs Rum yönetimi bu raporu olumlu karşılamıştır. Makarios yönetimi bu raporun kendileri açısından avantajlı etkisiyle, konuyu Birleşmiş Milletler Genel Kuruluna götürmüştür. Genel Kurul 18 Aralık 1965'te Kıbrıs Türklerinin azınlık olduğunu iddia eden 2077 sayılı kararı çıkarmıştır. ${ }^{11}$

Genel Kurul'da anılan kararın oylanmasında yalnızca Türkiye ile birlikte Arnavutluk olumsuz oy kullanmış, 54 üye ülke çekimser kalmış ve 47 ülke olumlu oy kullanmıştır. Bundan sonra Rum Yönetimi Kıbrıs'ın yegâne Hükümeti sayılmaya başlanmış ve Kıbrıs'ta yönetim Rumların ellerine geçmiştir. Türkler ve Türk idareciler göz ardı edilmeye başlanmıştır. Ateşkes hükümleri öne sürülerek Kıbrıslı Türklere, tam bir ambargo uygulanmaya başlanmıştır. ${ }^{12}$

Galo Plaza raporunun uygulanmasının imkânsız olduğu görüldüğünden Türkiye ile Yunanistan arasında 1965 Mayıs ayından itibaren görüşmelere başlanmış ancak 1966 yılı sonuna kadar hiçbir sonuç elde edilememiştir. Bunda Makarios ve Kıbrıslı Rumlar'ın konunun Birleşmiş Milletlere götürülmesinde ssrar etmesi ve Yunanistan iç politikasında yaşanan gergin günler etkili olmuştur. ${ }^{13}$

1964 ve 1965 dönemi Türkler için hayatlarını güvende hissetmedikleri yıllar olmuştur. Bu şartlarda, Kıbrıslı Türkler garantör devletlerden biri olarak Türkiye'ye başvurmuştur. Türkiye de bu durumu uluslararası organizasyonlar olan NATO ve CENTO' da gündeme getirmiştir. 1965-1966 yıllarında ufak tefek çatışma ve saldırılar yaşanmakla birlikte, bu dönemde nispi bir sükûnetin

\footnotetext{
${ }_{9}^{9}$ Baskın Oran, Türk Dış Politikası, İletişim Yayınları, İstanbul, 2001, s.733.

${ }^{10}$ Fahir Armaoğlu, 20.Yüzyıl Siyasi Tarihi, c.1, Türkiye İş Bankası Kültür Yayınları, İstanbul, 1992, s.793.

${ }^{11}$ Necati Münir Ertekün, The Cyprus Dispute, University Press, Oxford, 1981, s.21.

${ }^{12}$ Rauf Denktaş, The Cyprus Triangle, K.Rustem\&Brother/George Allen\&Unwin, London, 1982, s.50.

${ }^{13}$ Armaoğlu, a.g.e., s.794.
} 
hâkim olmuştur. EOKA ${ }^{14}$ 'nın saldırıları devam etmiş, Rumlar ve Türkler arasında küçük çatışmalar yaşanmıştır.

Kıbrıs Sorunu'nun çözümüne yönelik Mayıs 1965'te başlayan görüşmeler 1967 yılına kadar sürmüştür. Görüşmelerin devam ettiği bu süreç içerisinde Rum tedhiş hareketleri durmamış, Türk köylerine ve yerleşim yerlerine baskınlar düzenlenmeye devam etmiştir. 15 Kasım 1967 tarihinde Boğaziçi (Ayios Theodoros) ve Geçitkale (Kophinou) köylerini abluka altına alan Rum çeteleri 28 Kıbrıslı Türk'ü katletmiştir. ${ }^{15} \mathrm{Bu}$ gelişmeler üzerine Türkiye, saldırıların derhal durdurulmasını, işgal edilen Türk köylerinin boşaltılmasını istemiş ve gerekirse Yunanistan'a savaş açacağını bildirmiştir. ${ }^{16}$

Boğaziçi (Ayios Theodoros) ve Geçitkale (Kophinou) köylerine yönelik saldırıların başlamasıyla Türk hükümeti derhal acil toplanarak durum değerlendirmesi yapmış ve 16 Kasım 1967'de Meclisten, Kıbrıs'a asker çıkarmaya yönelik olarak, Türk Silahlı Kuvvetlerinin yabancı ülkelerde kullanımı konusunda 435 üyenin 432'si lehte, biri aleyhte olmak üzere çok büyük bir çoğunlukla yetki alınmıştır. ${ }^{17}$ Ertesi gün dost ve müttefik kuvvetlere, Ada'ya çıkarma yapılacağı bildirilmiştir. ${ }^{18}$

Türkiye'nin bu açıklaması üzerine ABD, devreye girerek müdahaleyi önlemiştir. Bununla birlikte Türkiye bazı isteklerini Rumlara kabul ettirmiştir. Bu kapsamda Türklerin yoğun olarak yaşadıkları yerlerde Geçici Türk Yönetimi kurulmuştur. Ayrıca, mevcudu yaklaşık 20.000 olan Yunan askeri adayı terk etmiştir. Bu karar çerçevesinde Grivas, adayı terke zorlanmıştır. Sıkıntının bu şekilde giderilmesinin ardından Kıbrıslı Türkler 29 Aralık 1967 tarihinde, 1960 Anayasasının bütün hakları alınıncaya kadar Kıbrıs Geçici Yönetimini kurmuştur. Geçici Türk Yönetimi Başkanlığına Fazıl Küçük, yardımcılığına ise Türk Cemaat Meclisi Başkanı Rauf Denktaş getirilmiştir. Bu şekilde, Rum zulmünden kaçan Kıbrıslı Türkler, yoğun olarak yaşadıkları bölgelerde kendi

\footnotetext{
${ }^{14}$ EOKA: Ada'yı Türklerden temizlemek ve Enosisi gerçekleştirmek için 1955 yılında kurulmuş olan bir Rum yer altı terör örgütüdür. Sabahattin İsmail, 150 Soruda Kıbrıs Sorunu, İstanbul, 1998, s.29-31.

15 Ümit Halûk Bayülken, "The Cyprus Question and the United Nations," Foreign Policy (Dış Politika), Vol.4, No.2-3 (1974), s.71-142.

${ }^{16}$ Yasin Coşkun, "Kıbrıs Sorunu Üzerindeki Türk-Yunan Diyaloğunun Başarısızlığı (1966-67) ve İngiliz Politikası", Karatekin Edebiyat Fakültesi Dergisi, 4/1, Çankırı, 2014, s.54.

${ }_{17}$ BCA, 030.01/16.89.10, 30 Kasım 1967; Dışişleri Belleteni, S.38, Kasım 1967, s.22-24; Abdulhaluk Çay, Kıbrıs'ta Kanlı Noel-1963, Türk Kültürü Araştırma Enstitüsü Yayınları, Ankara, 1989, s.8485.

${ }^{18}$ Armaoğlu, a.g.e., s.798-799.
} 
yönetimlerine kavuşmuş ve Kıbrıs'ta federe bir yönetime giden adım atılmıştır. Rauf Denktaş 13 Nisan 1968 tarihinde Kıbrıs'a dönmüştür. ${ }^{19}$

Türk-Yunan ilişkilerinde ilerleme kaydedilmiş, Mart ve Nisan 1968 tarihinde iki ülke başkentlerinde dışişleri yetkilileri toplanmış, Mayıs 1968 tarihinde de Viyana'da bir araya gelerek anlaşma sağlanan konuları içeren bir rapor düzenlemiştir. Bunun sonucunda, Birleşmiş Milletler Genel Sekreteri U Thant'tın 13 Mart tarihli raporu sonucunda Kıbrıslı Türk ve Rum temsilciler müzakerelere davet edilmiştir. ${ }^{20}$ Görüşmeler 3 Haziran 1968'de Türk Cemaat Meclisi Başkanı Rauf Denktaş ile Rum Temsilciler Meclisi Başkanı Glafkos Klerides arasında Lefkoşa'da başlamıştır. Bu görüşmeler Birleşmiş Milletler Genel Sekreterinin Kıbrıs Özel Temsilcisi B.F. Osorio-Tafall'in gözetiminde 20 Eylül 1971 tarihine kadar devam etmiştir. ${ }^{21}$ Ancak enosis idealinden vazgeçmeyen Rumlar, görüşmelerde takındıkları uzlaşmaz tavırlarda ısrar ettiklerinden hiçbir ilerleme kaydedilememiştir. ${ }^{22}$ Görüşmeler önce Denktaş, Klerides ve B.F.Osorio-Tafall gözetiminde üçlü şekilde başlamış daha sonra Türkiye Cumhuriyeti adına Orhan Aldıkaçtı ve Yunanistan adına da Mihail Dekleris'in katılımıyla beşli şekilde devam etmiştir. ${ }^{23}$

Kıbrıs'ı terk eden Grivas, 1971 yılında Ada'ya geri dönmüştür. Ardından da EOKA-B'yi kurduğunu açıklamıştır. Ancak, adayı Yunanistan'a bağlamak düşüncesinde olan Grivas'1, Makarios kabul etmemiştir. Bunun üzerine Yunan yönetimi, Makarios'u öldürmek ve yerine Yunanistan yanlısı birini işbaşına getirmek için harekete geçmiştir. ${ }^{24}$

15 Temmuz 1974 sabahı Nikos Sampson'un başını çektiği Rum Milli Muhafız Ordusu, arasında üç tankın bulunduğu Rum birlikleri

\footnotetext{
${ }^{19}$ Yavuz Güler, "Kuzey Kıbrıs Türk Cumhuriyeti'nin Kuruluşuna Kadar Kıbrıs Meselesi", Gazi Üniversitesi Kırşehir Eğitim Fakültesi Dergisi, Ankara, 2004, 5/1, 101-112; Sabahattin İsmail, Kıbrıs Cumhuriyeti'nin Doğuşu ve Çöküşü ve KKTC'nin Kuruluşu (1960-1983), İstanbul, 1992, s.4; Melek Fırat, "1945-1960 Yunanistan'la İlişkiler," Baskın Oran (ed.), Türk Dış Politikası, Kurtuluş Savaşından Bugüne Olgular, Belgeler, Yorumlar, Cilt I, 8. Baskı, İstanbul, İletişim Yayınları, 2003, s.226.

20 Armaoğlu, a.g.e., s.800.

${ }^{21}$ Ertekün, a.g.e., s.25.

${ }^{22}$ Zehra Yalçınkaya Cerrahoğlu, Birleşmiş Milletler Gözetiminde Kıbrıs Sorunu ile İlgili Olarak Yapılan Toplumlararası Görüşmeler 1968-1990, T.C. Kültür Bakanlığı Yayınları/2061, Ankara, 1998, s.28.

${ }^{23}$ Şevki Kıralp, “1967-1974 Döneminde Kıbrıs Sorunu ve Türkiye ile Yunanistan'ın Kıbrıs Politikaları", Journal of History Culture and Art Research, 7(2), s.444-460.

${ }^{24}$ Mustafa Tarakçı, Kıbrıs Barış Harekâtı, Hiperlink Yayınları, İstanbul, 2010, s.10; Vehbi Zeki Serter, “Kıbrıs' ta 15 Temmuz 1974'te Düzenlenen Rum-Yunan Askeri Darbesi ve Mutlu Türk Barış Harekâtı'nın Başlaması (20 Temmuz 1974)", Türk-Yunan İlişkileri Bildirileri, Üçüncü Askeri Tarih Semineri, Genelkurmay Basımevi, Ankara, 1986, s.347.
} 
Cumhurbaşkanlığı sarayına saldırmıştır. ${ }^{25} \mathrm{Bu}$ darbe girişimi sonucu kritik bölgeler isyancıların eline geçince, Makarios Ada'dan kaçmıştır. Gelişen bu durum karşısında adadaki Türk direnişini örgütleyen liderlerden biri olan Rauf Denktaş, Türkiye'nin duruma müdahale etmesini istemiştir. ${ }^{26}$ Makarios'un kaçışından sonra yerine cumhurbaşkanı arayışına girişilmiştir. Bu kapsamda cuntacılar tarafindan önce bir iş adamı olan Zinona Severi'ye bu görev önerilmiştir. Ancak o, bu öneriyi kabul etmeyince Nikos Sampson, Cumhurbaşkanlığına getirilmiştir. ${ }^{27}$

Bu sırada 19 Temmuz 1974 tarihinde Birleşmiş Milletler Güvenlik Konseyi'nde bir konuşma yapan Makarios: "Yunanlılar Kıbrıs' $\imath$ işgal etmişlerdir. Büyük binalarda Yunan bayrakları dalgalanmakta ve ambulanslar sürekli olarak yaralı taşımaktadırlar. Yunanlılar Türklerden daha çok tehlikelidirler. Çarpışmalar kanlı bir şekilde devam etmektedir. Türkler de büyük tehlike içindedirler. Bu işgal harekâtı Kıbrıs'ın bağımsızlı̆̆ııı tamamen ortadan kaldırmıştır" demiştir. ${ }^{28}$ Kıbrıs'ta yönetimi ele geçiren darbeciler, sıkıyönetim ilan etmiş bu suretle adadaki şehirlerin kontrolünü ellerine geçirmiştir. Darbecilerin lideri Nikos Sampson Ada'da Helen Cumhuriyetinin kurulduğunu açıklamıştır. ${ }^{29}$

Türkiye, Rum-Yunan ikilisinin Kıbrıs'ta 15 Temmuz 1974'te gerçekleştirdiği hükümet darbesine sert bir tepki vererek bu darbeyi adada anayasal düzenin yıkılması, 1960 antlaşmalarının çiğnenmesi olarak değerlendirmiş ve darbeyle iş başına gelen Rum idaresinin üstü örtülü bir Enosis olduğunu vurgulayarak bu sebeple gayri meşru bu yeni idareyi tanımadığını tüm dünyaya ilan etmiş ve garantör devlet olarak bu durumun önlenmesine karar vermiştir. ${ }^{30}$

Kıbrıs'taki darbe girişiminden sonra Türkiye, 18 ve 19 Temmuz günlerinde, İngiltere ve ABD ile bütün diplomatik yolları deneyerek, sorunu barışçıl yollardan çözmeye çalışmıştır. Ancak Yunanistan, Ada'dan EOKA'c1 Nikos Sampson'u çıkarmaya yanaşmamış, Kıbrıs'ta meşru yönetimin

\footnotetext{
${ }^{25}$ Mustafa Yeniasır-Burak Gökbulut-İsmail Tamer, “Ahmet Gazioğlu'nun Kıbrıs'ta Aşk ve Savaş Adlı Romanına 1974 Kıbrıs Türk Barış Harekâtı'nın Yansıması", Selçuk Üniversitesi Edebiyat Fakültesi Dergisi, 2020; (43): 149-182.

${ }^{26}$ Mesut Günsev, Şafak Vakti Kıbrıs'ta (20 Temmuz 1974), Kastaş Yayınları, İstanbul, 1999, s.120122; Sevim Toluner, Kıbrıs Uyuşmazlığı ve Milletlerarası Hukuk, İstanbul Üniversitesi Hukuk Fakültesi Yayınları, İstanbul, 1977, s.253.

${ }^{27}$ Atasever, a.g.m., s.1515; Güvenlik Kuvvetleri Dergisi, Sayı: 18, Lefkoşa, 1989, s.14.

${ }_{28}$ Başbakanlık Devlet Arşivleri Genel Müdürlüğü, Osmanlı İdaresinde Kıbrıs (Nüfusu, Arazi Dağıllımı ve Türk Vakıflar), Ankara, 2000, s.75.

${ }^{29}$ Osman M. Öztürk, Stratejik Açıdan Doğu Akdeniz ve Kıbrıs, Altınküre Yayınları, No: 8, 1. Baskı, Ankara, 2003, s.37.

${ }^{30}$ Ali Fikret Atun, Avrupa Birliği ve Kıbrıs'ın Avrupa Birliğine Üyeliği, Kıbrıs Türk Mücahitler Derneği Yayınları, No: 10, Lefkoşa, 2001, s.50.
} 
oluşmasına gayret ve çaba göstermemiştir. Diplomatik yollardan yapılan bütün bu girişimler, Yunanistan tarafından reddedilmiştir. Bu girişimlerin sonuçsuz kalması üzerine, Türkiye Garanti Antlaşmasına dayanarak yükümlülüklerini yerine getirmek üzere müdahale yetkisini kullanmaya mecbur kalmıştır. ${ }^{31}$

\section{Birinci Harekâtın Başlaması ve Gelişmeler}

Harekât öncesinde yapılan ve beş gün süren Milli Güvenlik Kurulu Toplantısında Cumhurbaşkanı Fahri Korutürk, Başbakan Bülent Ecevit, Başbakan Yardımcısı Prof. Dr. Necmettin Erbakan, Genel Kurmay Başkanı Orgeneral Semih Sancar, Bakanlar ve Kuvvet Komutanları Kıbrıs sorununu görüşmüştür. Toplantıda son gelişmeler 1şı̆̆ında durum değerlendirmesi yapilmıştır. ${ }^{32}$

17 Temmuz 1974 günü düzenlenen Milli Güvenli Kurulu toplantısında Barış Harekâtının yapılacağı gün kesinleşmiştir. Toplantıda Başbakan Bülent Ecevit kuvvet komutanlarına, “Ayın 20'sine hazır misınız?" sorusunu yöneltmiştir. Hava ve Deniz Kuvvetleri Komutanları hazır olduklarını söylerken, Kara Kuvvetleri Komutanı 20 gün ilave süre talep etmiştir. Başbakan ise bunun mümkün olmayacağını, bir an önce harekete geçmeleri gerektiğini söylemiştir. Neticede 20 Temmuz 1974 tarihi harekât günü olarak belirlenmiştir. ${ }^{33}$ İkinci Taktik Hava Kuvvet Komutanı Hava Pilot Tümgeneral Hulusi Kaymaklı'nın tatili yarıda kesilerek Ankara'ya gelmesi sağlanmış ve durum kendisine izah edilmiştir. MGK toplantısında, havacıların 18 Temmuz 1974 tarihinde Adana'da Müşterek Harekât Merkezinde olmaları karara bağlanmıştır. 18 Temmuz 1974 tarihinde Hv.Plt.Tümg. Hulusi Kaymaklı ve Kara Kuvvetleri Komutanı Orgeneral Eşref Akıncı bir C-47 nakliye uçağ1 ile Adana'ya inmiş ve İntikal edecek birlik komutanları da İncirlik'e çağrılmıştır. ${ }^{34}$

Kıbrıs Barış Harekâtının ilk safhası olan 20-22 Temmuz 1974 tarihleri arasında; 1'inci Ana Jet Üs Komutanlığından 111'inci (F-100D/F) ve 112'nci Filolar (F-100C/F), 3'üncü Ana Jet Üs Komutanlığından 131'inci ve 132'nci Filolar (F-100C), 4'üncü Ana Jet Üs Komutanlı̆̆ından 141'inci Filo (F-104G), 5'inci Ana Jet Üs Komutanlığından 152'nci Filo (F-5), 7'nci Ana Jet Üs Komutanlığından 171'inci ve 172'nci Filolar (F-100D/F), 8'inci Ana Jet Üs Komutanlığından 181'inci (F-100C/F) ve 184'üncü Filolar (RF-84F) ile 9'uncu

\footnotetext{
${ }^{31}$ Rifat Uçarol, Siyasi Tarih, Filiz Kitabevi, İstanbul, 2000, s.769.

${ }^{2}$ Erol Mütercimler, Bilinmeyen Yönleriyle Kıbrıs Barış Harekâtı, Arba Yayınları, İstanbul, 1998, s.156.

${ }^{33}$ Denizli, a.g.e., s.163.

${ }^{34}$ Mustafa Tarakçı, Kıbrıs Barış Harekâtı, Hacettepe Üniversitesi Atatürk İlkleri ve İnkılap Tarihi Enstitüsü, Yayınlanmış Doktora Tezi, Ankara, 1998, s.83.
} 
Ana Jet Üs Komutanlığından 191'inci (F-104) Filolarda bulunan muharip uçaklar ile 12'nci Hava Ulaştırma Ana Üs Komutanlığ 1 Ulaştırma Filolarındaki (C-47, C-160, C-130) nakliye uçakları çeşitli görevler icra etmiştir. Harekâta iştirak edecek filolar 19 Temmuz 1974 tarihinden itibaren yeni meydanlara intikal etmiştir. ${ }^{35} \mathrm{Bu}$ kapsamda Malatya' da konuşlu bulunan 171'inci ve 172 'nci Filolar ile Diyarbakır'da konuşlu olan 181'inci Filo'nun yarısı ile 184'üncü Filo'nun yarısı İncirlik'e, 181'inci Filo'nun diğer yarısı ile Merzifon'da konuşlu olan 152'nci Filo'nun yarısı Antalya'ya, Konya'da konuşlu bulunan 131'inci Filo Balıkesir'e, Eskişehir'de konuşlu olan filolardan 112'nci Filo Sivrihisar'a ve Balıkesir'de konuşlu olan filolardan 191'inci Filo Mürted Hava Üssüne intikal etmiştir. ${ }^{36}$

Türkiye harekât için hazırlıklarını yaparken Yunanistan'da Kıbrı'lı Rumlara destek vermek amaciyla üç adet F-4 savaş uçağ 1 ile bir denizaltı görevlendirmiştir. Harekât öncesinde Girit'e intikal eden savaş uçaklarından biri, iniş sırasında hasar görmüş, diğer ikisi ise Girit'te kalmıştır. Denizaltı ise Türkiye harekâta başladığı zaman geri çağrılmıştır. ${ }^{37}$

Harekât planına göre; İlk olarak Girne'den giriş yapılacak ve hava indirme tugayıyla da paraşütlerle askerler Beşparmak Dağları'nın Lefkoşa tarafına indirilecekti. Girne ve Lefkoşa arasındaki Beşparmak Dağları temizlenecek ve sonradan gelen birlikler için bir koridor açlacaktı. Açılacak koridor ile birlikler Mağosa ve Erenköy'e doğru hareket edeceklerdi. Harekâtın planlaması, büyük bir titizlik içerisinde gerçekleşmiş, Rumlardan temizlenecek veya alınacak olan yerler de belirlenmişti. Kıbrıs Barış Harekatı'na 6'ncı Kolordu Komutanlığ 1 emrinde; 28' inci Motorlu Piyade Tümeni, 39'uncu Piyade Tümeni, Hava İndirme ve Komando Tugayları, Gösteri Tatbikat Alayı, Amfibi Deniz Piyade Alayı, Jandarma Komando Taburları, Deniz ve Hava Kuvvetleri birlikleri, Çakmak Özel Görev Kuvveti, Bayraktarlık emrindeki Mücahit Birlikleri, 650 kişilik Kıbrıs Türk Alayı ile idari ve lojistik destek birlikleri katılmıştır. Harekât üç safha olarak planlanmıştır. Birinci safhada hava ve kıyı başının tesisi ve elde bulundurulması, ikinci safhada çıan ve indirilen birliklerin birleşmesi, üçüncü safhada da harekât alanının genişletilmesi öngörülmüştür. ${ }^{38}$

\footnotetext{
${ }_{35}$ Ali Fikret Atun, İkinci Kıbrıs Seferi 20 Temmuz 1974, Harp Akademileri Basımevi, İstanbul, 1999, s.64.

${ }^{36}$ Genelkurmay Başkanlığı Kıbrıs Türk Barış Kuvvetleri Komutanlığı, Sebep ve Sonuçlarıyla 1974 Kıbrıs Barış Harekâtı, Genelkurmay Başkanlığı Kıbrıs Türk Barış Kuvvetleri Komutanlığı Yayını, Özdilek Matbaası, Lefkoşa, 1996, s.186.

37 Özdemir, a.g.m., s.490.

${ }^{38}$ Ferhat Apuhan, 1974 Kıbrıs Barış Harekâtı ve Bingöllü Kıbrıs Gazileri, Yüzüncü Yıl Üniversitesi Sosyal Bilimler Enstitüsü, Yayımlanmamış Yüksek Lisans Tezi, Van, 2017, s.77; İbrahim Artuç, Kıbrıs'ta Savaş ve Barış, Kastaş Yayınları, İstanbul, Eylül 1989, s.167-169.
} 
Başbakan Ecevit 20 Temmuz 1974 tarihinde harekâtla ilgili verdiği demeçte "Kıbrıs'a barış için gidiyoruz" demiştir. Türkiye'nin Kıbrıs'ta dökülen kanları durdurmak amacıyla uluslararası antlaşmalardan doğan hakkını kullandığının altını çizen Ecevit, adayı işgal etmek amacı ile değil Kıbrıs toplumunun can ve mal güvenliğini garanti altına almak için böyle bir barış harekâtına girişildiğini açıklamıştır. ${ }^{39}$

Ada'daki durumun kritik bir aşamaya gelmesi üzerine Türkiye, Londra ve Zürih Antlaşmalarının kendisine verdiği garantörlük haklarını kullanarak 20 Temmuz 1974'te; Kara, Deniz ve Hava Kuvvetlerinin katkıları ile Kıbrıs'a müşterek bir harekât başlatmıştır. Türkiye ilgili günün gecesi, kuvvetlerini gemilere bindirip hazırlıklarına hız vermiştir. Harekât, ilk olarak beş muhrip, dört denizaltı, beş koruma hücum botu ve otuz bir çıkarma gemisiyle yaklaşık 2000 askerle başlamıştır..$^{40}$ Türk Silahlı Kuvvetleri 20 Temmuz sabahı Türk Hava Kuvvetlerinin desteğiyle eş zamanlı olarak hem Girne plajlarına çıkarma yapmış, hem de Lefkoşa-Girne yolu üzerinde ve Lefkoşa yakınlarındaki Gönyeli'de hava indirme görevi icra etmiştir. ${ }^{41}$ Aynı dönemde Türk jetleri, çıkarma harekâtı öncesinde Girne'nin batısındaki Pladini plajının ilerisindeki dağlarda belirlenen hedefleri bombalamışır. Bu sırada Girne Stadyumu civarındaki zırhlı Rum birlikler ve cephanelik haline getirilmiş yerler Türk uçakları tarafından imha edilmiştir. Ayrıca çıkarma esnasında Türk gemilerine müdahaleye hazırlanan Rum Milli Muhafız Ordusu'na ait bir hücumbot Türk savaş uçakları tarafından etkisiz hale getirilmiştir. ${ }^{42}$

20 Temmuz 1974 tarihinde 2'nci Taktik Hava Kuvveti Komutanlığ emrine tahsis edilen filolarla harekâtın hava desteği sağlanmış ve 12'nci Hava Ulaştırma Ana Üs Komutanlığının imkânlarının tümü kullanılarak hava indirme harekâtı gerçekleştirilmiştir. ${ }^{43}$ Genelkurmay Başkanlığı tarafından Hava Kuvvetleri Komutanlığına verilen direktifte; "Genel bir bombardiman yapılmayacak, sadece çıkarma ve indirme bölgelerindeki hedeflere taarruz edilecek ve bu taarruz esnasında karşı taraf ateş açmadıkça ateş edilmeyecek." kısıtlamaları gereği Rum Milli Muhafız Ordusu'nun uçaksavarlarının ilk ateşine kadar bu emre uyulmuştur. ${ }^{44}$

\footnotetext{
39 Şerafettin Turan, Türk Devrim Tarihi IV Çağdaşlık Yolunda Yeni Türkiye (İkinci Bölüm), Bilgi Yayınevi, 1. Baskı, Ağustos 1999, s.65.

${ }^{40}$ Apuhan, a.g.e., s.77.

${ }^{41}$ Armaoğlu, a.g.e., s.803.

${ }^{42}$ Mütercimler, a.g.e., s.268.

${ }^{43}$ Genelkurmay Başkanlığı Kıbrıs Türk Barış Kuvvetleri Komutanlığı, a.g.e., s.186.

${ }^{44}$ Atasay Özdemir, "1974 Kıbrıs Barış Harekâtı Kapsamında Türk Hava Kuvvetleri Tarafından İcra Edilen Hava Harekâtı ve Görevleri Üzerine Bir Değerlendirme", Türk Hava Kuvvetlerinin 100'üncü Yılı Uluslararası Ta6rih Sempozyumu, Ayrıntı Basımevi, Ankara, 2013, s.491.
} 
Hava indirme harekâtı için görevlendirilen 12'nci Hava Ulaştırma Üs Komutanlığı'nda konuşlu olan C-47, C-160 ve C-130 uçaklarından C-47'ler paraşüt taburunun hava indirmesi ile görevlendirilirken; C-160 ve C-130'lar hava indirme görevinin yanında havadan malzeme atmakla da görevlendirilmiştir. 20 Temmuz 1974 sabahı saat 05.00 itibarıyla Kayseri'den havalanan uçaklar radara yakalanmamak için alçak uçuş yaparak Kıbrıs istikametinde ilerlemiştir. ${ }^{45} \mathrm{Bu}$ sırada hava indirme görevi icra edecek olan ulaştırma uçakları ve helikopterler 152'nci Filo Komutanlığına bağlı F-5 savaş uçakları tarafından himaye edilmiştir. ${ }^{46}$

Saat 07.05 'te ulaştırma uçakları ile taşınan ilk Türk kuvvetleri harekât bölgesine atlatılmıştır. Özellikle ulaştırma uçaklarının kapasitesinin sınırlı olmasından dolayı ilk etapta yalnızca iki tabur asker taşınabilmiştir. İndirme esnasında Rum Milli Muhafız Ordusu (RMMO) birliklerince Lefkoşa bölgesindeki mevzilerden uçaklara ateş açılmıştır. Ancak, 1'inci ve 2'nci Paraşüt Taburları inerken ciddi bir Rum ateşi ile karşılaşmamıştır. Bu sırada 3'üncü ve 4'üncü Paraşüt Taburlarını almak için Kayseri'ye dönen uçakların arızalanması üzerine planlamada değişiklik yapılmak zorunda kalınmıştır. Bu kapsamda ağır malzeme atmakla görevlendirilen C-130 ve C-160 uçakları, paraşüt taburlarının indirilmesi için görevlendirilmiştir. Bu durum hem paraşüt taburunun hem de harekât bölgesine gönderilecek ağır malzemelerin atılmasında gecikmeler yaşanmasına etki etmiştir. Harekât boyunca 12'nci Hava Ulaştırma Ana Üs Komutanlığı tarafından 132 sorti yapılmak suretiyle malzeme ve personel taşınmıştır. ${ }^{47}$

Uçakların ikinci kafileyi getirmesi beş saat sürmüştür. Saat $11.05^{\prime}$ te 3'üncü Paraşüt Taburu Pınarbaşı'na, 4'üncü Paraşüt Taburu Gönyeli'ye inmiştir. 3'üncü ve 4'üncü Paraşüt Taburları ilk inen taburlar kadar şanslı olmamıştır. Yoğun topçu ve hava ateşine tutulmuşlardır. Bu nedenle dağınık olarak inen taburlar bir hayli zor şartlar altında toparlanabilmiştir. 1'inci Paraşüt Taburu, Dağ Yolu ile Karatepe arasındaki bölgeyi savunurken, 2'nci Paraşüt Taburu yoğun ateş nedeniyle Pınarbaşı'nda kalarak, bir bölüğünü Kıbrıs Türk Alayı emrine vermiştir. 3'üncü Paraşüt Taburu gece yarısından önce Türk Boğazı'nı ele geçirmiştir. Komando Tugayı da 20 Temmuz 1974 sabahı harekete geçmiştir. Bu kapsamda Komando Tugayı'nın 1'inci Komando Taburu saat 07.40 'ta Ovacık'tan 72 helikopterle havalanmıştır. Böylece, dünya tarihinde ilk kez bu kadar çok helikopter kullanmak suretiyle bir harekât icra

\footnotetext{
${ }^{45}$ Erol Mütercimler, Kıbrıs Barış Harekâtının Bilinmeyen Yönleri: Satılık Ada Kıbrıs, Alfa Basım Yayım Dağıtım Tic.Ltd.Şti., 5. Baskı, İstanbul, 2007, s.273-277.

${ }^{46}$ Cumhur Evcil, Yavru Vatan Kıbrıs'ta Zaferin Hikâyesi, Genelkurmay Askerî Tarih ve Stratejik Etüt Başkanlığı Yayınları, Ankara, 1999, s.31.

${ }^{47}$ Genelkurmay Başkanlığı Kıbrıs Türk Barış Kuvvetleri Komutanlığı, a.g.e., s.186.
} 
edilmiştir. 40 dakika süren yolculuktan sonra 1'inci Komando Taburu saat 08.20'de Pınarbaşı'na inmiştir. Ovacık'a gidip 2'nci Komando Taburu'nu yükleyen helikopterlerin tekrar Kıbrıs'a dönmesi üç saati bulmuştur. 2'nci Komando Taburu da Pınarbaşı'na saat 11.45'te inmiştir. 3'üncü Komando Taburu dört saat sonra saat $15.45^{\prime}$ te Gönyeli'ye inmiştir. Nevşehir Jandarma Komando taburu saat 18.45 'te Hamitköy'e inmiştir. Bu sırada 3'üncü Komando Taburu'nun bir bölüğ̈̈ Kıbrıs Türk Alayı emrine girmiştir. ${ }^{48}$

Nevşehir Jandarma Komando Taburu, Lefkoşa-Girne yolundaki Dikmen Köyü istikametine yerleştirilmiştir. Bu sırada tank ve zırhlı araçlarla takviyeli Yunan Alayı, Kıbrıs Türk Alayı'na karşı taarruza başlamıştır. Yunan Alayı bu harekât ile Kıbrıs Türk Alayı'nı Gönyeli üzerinden kuşatarak imha etmeye çalışmıştır. Bu durum üzerine 4'üncü Paraşüt Taburu, Kıbrıs Türk Alayı'nın emrine verilmiştir. Kıbrıs Türk Alayı, Yunan Alayı'nın saldırısını başarı ile önlemiş ve bu taarruzu püskürtmüştür. Diğer taraftan Rum Milli Muhafız Ordusu kuvvetleri, Girne Boğazı'nın batısındaki Doğruyol tepesini 29 Kıbrıslı Türk mücahidi şehit ederek işgal etmiş ve Girne Boğazı'na hâkim olmuştur. Kuzey Kıbrıs kıyıları boyunca uzanan yüksek ve ormanlık Beşparmak Dağları, inen birliklerle çıkan birlikleri bir duvar gibi ayırdığından, Lefkoşa-Girne yolunun geçtiği bölgenin temizlenmesi gerekmiştir. Bu nedenle 1'inci Komando Taburu, Doğruyol Tepesi'ne karşı taarruza başlamış ve sabaha kadar ilgili bölgeyi ele geçirerek, Girne Boğazı'nı kontrol altına almıştır. 2'nci Komando Taburu da Girne Boğazı'nın kuzey sırtlarını temizleyerek güvenlik altına almiştır. $^{49}$

Harekât sırasında Rum Milli Muhafiz Ordusu'na ait top ve uçaksavarlarla Türk savaş uçaklarına yerden ateş açılmıştır. Girne Kalesi'ne yerleştirilen Rum uçaksavarlarının ateşi sonucu iki Türk F-100 savaş uçağ1 vurulmuş, pilotlar bu ateşten paraşütle atlamak suretiyle kurtulmuştur. ${ }^{50}$ Aynı dönemde 20 Temmuz 1974 tarihinde RF-84F uçağı ile keşif uçuşu yapan Hava Pilot Üsteğmen İlker Karter, yerden açılan uçaksavar ateşi sonucu uçağının vurulması neticesinde Deregeçit mevkiine düşerek şehit olmuştur. ${ }^{51}$

Türk savaş uçaklarına yerden yapılan yoğun uçaksavar ateşi Türk Hava Kuvvetleri'nin harekâtını etkilememiştir. Bu sırada Marmari'de konuşlu

48 Gökhan Baday, 1974 Kıbrıs Barış Harekâtı ve Kars-Ardahan Kıbrıs Şehitleri İle Gazileri, Yayımlanmamış Yüksek Lisans Tezi, Kafkas Üniversitesi Sosyal Bilimler Enstitüsü, Kars 2009, s.44.

${ }^{49}$ Turan Erdem, Kıbrıs Barış Harekâtında 3'üncü Paraşüt Taburu, Genelkurmay ATASE Başkanlığ1 Yayınları, Genelkurmay Basımevi, Ankara, 1999, s.20-23.

${ }^{50}$ Mütercimler, a.g.e., s.265-267.

${ }^{51}$ Hava Kuvvetleri Komutanlığı, Hava Şehitleri Albümü, Cilt III, Hava Basımevi, Ankara, 1999, s.138. 
bulunan Rum Milli Muhafız Ordusu'na ait tank taburu Türk savaş uçaklarının taarruzları ile dağıtılmıştır. Hava taarruzu sonrasında Rum Tank Taburu'ndan yalnızca 8-10 tank kurtulabilmiştir. Türk savaş uçakları, Rum Milli Muhafız Ordusu'nun Lefkoşa içinde bulunan savunma mevzileri ile Girne'deki Rum kuvvetleri garnizonunu takviye etmeye çalışan iki motorlu yürüyüş kolunu imha etmiştir. ${ }^{52}$ Aynı dönemde Rum Milli Muhafız Ordusu birlikleri tarafından Erenköy'e yapılan taarruz Türk savaş uçaklarının yaptığı isabetli atışlarla engellenmiştir. ${ }^{53}$

İlk yapılan harekât sonucunda; Rumlar beklemedikleri yer ve zamanda baskına uğramıştır. Bu sebeple Türk kuvvetlerine karşı etkili müdahalede bulunamamışlardır. Ancak Türk kuvvetleri de istediği hedeflere ulaşamamıştır. Rum kuvvetlerinin yoğun ateşi, aksaklıklar, irtibatın kesilmesi, yorgunluk ve intikallerin gecikmeli yapılması istenilen hedeflere ulaşmayı engellemiştir. Dolayısıyla Beş Parmak Dağlarında istenilen yerler ele geçirilememiştir. Türk uçakları Rumların etkili savaşmalarını önlemiş, stratejik noktaları vurarak kuvvetlerin önünü açmıştır. İlk gün Kırnı, Gönyeli, Orta köy Rum kuvvetlerinin eline geçmiş, ancak tekrar geri alınmıştır. Yine ilk gün 5000 Türk kuvveti adaya ayak basmış, Kıbrıs Türk Mukavemet Teşkilatı ${ }^{54}$ (TMT) ile birlikte bu sayı 11.000 'i aşmıştır. ${ }^{55}$

Harekâtın ikinci gününde Rum kuvvetlerinin yoğun tank atışı sonucu 50'nci Piyade alayının karargâhı vurulmuştur. Rum saldırısı sırasında Alay Komutanı Piyade Albay İbrahim Karaoğlanoğlu ve bölgede ileri hava kontrolörü olarak görev yapan Hava Pilot Binbaşı Fehmi Ercan şehit olmuştur. 21 Temmuz 1974 saat 09.50'de yapılan çıkarma harekâtında hava ve deniz kuvvetleri arasındaki muhabere eksikliği nedeniyle Kocatepe savaş gemisi Yunan savaş gemisi zannedilerek batırılmıştır. Antalya'nın 160 kilometre güneyinde görevli bulunan deniz kuvvetlerine bağlı bir karakol uçağı, Yunan savaş gemileri desteğinde büyük bir deniz konvoyunun Kıbrıs'ın güney batısına doğru hareket ettiğini rapor etmiştir. Bunun üzerine Türk savaş uçakları söz konusu gemilere 14.15 sularında ateş ederek Kocatepe muhribini batırmış diğer gemileri de hasara uğratmıştır. Neticede istihbarat ve muhabere

\footnotetext{
${ }^{52}$ Pierre Oberling, Bellapais'e Giden Yol, Çeviren: Mehmet Erdoğan, Genelkurmay Askerî Tarih ve Stratejik Etüt Başkanlığı Yayınları, Ankara, 1988, s.132.

${ }^{53}$ Süleyman Koç, Dünden Bugüne Kıbrıs Sorunu ve Stratejik Yaklaşımlar, IQ Kültür Sanat Yayıncillk, İstanbul, 2005, s.223.

54 Türk Mukavemet Teşkilâtı (TMT): 1957 yılında Rumların ve EOKA'nın silahlı saldırılarına karşı Kıbrıs'ta yaşayan Türklerin korunmaları amacı ile Rauf Denktaş, Burhan Nalbantoğlu ve Kemâl Tanrısever'in öncülügünde kurulmuştur. İsmail, a.g.e., s.31-33.

${ }^{55}$ M. Şükrü Tandoğan, Kıbrıs Barış Harekâtı Birlikler ve Muharebeler, Türkiye Muharip Gaziler Derneği, Türmantsan Organize Matbaacılık, Ankara, 2015, s.43.
} 
eksiklikleri neticesinde meydana gelen olay sonucunda; 3'ü subay, 14'ü astsubay ve $37^{\prime}$ si er olmak üzere toplam 54 şehit verilmiştir. ${ }^{56}$

21 Temmuz 1974 günü Rum kuvvetlerinin yoğun taarruz ve saldırıları Türkleri zor durumda bırakmış ve Türk tarafı istenilen taarruzları gerçekleştirememiştir. Bununla birlikte 3'üncü Paraşüt taburu tarafından Rum boğazı ele geçirilerek buradaki Rum Milli Muhafız Ordusu kuvvetleri bozguna uğratılmıştır. Böylece, boğaza ve kolordu karargâhına yönelik Rum tehdidi büyük ölçüde ortadan kaldırılmıştır. ${ }^{57}$

Harekâtın üçüncü günü olan 22 Temmuz 1974 tarihinde, 39'uncu Piyade Tümeni'nin Ada'ya çıkışı ile Türk tarafı önemli başarılar elde etmiştir. 17.30'da Girne kalesi ele geçirilmiştir. Bu sırada Türk birlikleri birleşerek merkezi komuta altına alınmıştır. Bu kapsamda Tümgeneral Bedrettin Demirel, Kolordu Komutanı Nurettin Ersin'e komutayı devretmiştir. Aynı günün sonunda Beşparmak Dağlarında bulunan Şahinler ve Doğruyol bölgesi ile Bozdağ’ın kontrolü sağlanmıştır. Böylece genel anlamda başarılı olan harekât sonucunda adanın $\% 7^{\prime}$ si ele geçirilmiştir. ${ }^{58}$

Harekâtın bu ilk safhası kapsamında ulaştırma filoları tarafından 132 sorti görev icra edilmiştir. Neticede 171'inci Filo Komutanlığ tarafından 26 görev kapsamında 75 sorti, 172'nci Filo Komutanlığı tarafından 25 görev kapsamında 55 sorti, 131'inci Filo Komutanlığ 1 tarafından 30 görev kapsamında 89 sorti, 132'nci Filo Komutanlığı tarafından 26 görev kapsamında 73 sorti, 181'inci Filo Komutanlığ 1 tarafından 28 görev kapsamında 95 sorti, 184'üncü Filo Komutanlığı tarafından keşif görevi kapsamında 69 sorti yapılmıştır. 152'nci Filo Komutanlığg tarafından indirme ve çıkarma birliklerinin himayesi kapsaminda 111'inci, 112'nci, 191'inci ve 141'inci Filo Komutanlıkları tarafından da Baf bölgesindeki amfibi Rum konvoyuna taarruz görevleri icra edilmiştir. ${ }^{59}$ Harekatın ilk safhasında Türk Hava Kuvvetleri tarafından toplam 733 sorti icra edilmiştir. Bu görevler sırasında altısı F-100, biri F-104 ve bir diğeri RF-84F olmak üzere toplam sekiz uçak kaybedilmiştir. ${ }^{60}$

Kıbrıs Barış Harekâtının başarıyla ilerlediği bir evrede, ABD ve Birleşmiş Milletler'in isteği üzerine 22 Temmuz 1974 akşamından itibaren ateşkes kararı uygulamaya konulmuştur. ${ }^{61}$ Türk müdahalesi sonrasında, Nikos Samson hükümeti ve Yunanistan'daki askerî rejim yıkılmıştır. Kıbrıs'ta Rum Temsilciler

\footnotetext{
${ }^{56}$ Mütercimler, a.g.e., s.359.

57 Tandoğan, a.g.e., s.46.

58 Tandoğan, a.g.e., s.51.

${ }^{59}$ Genelkurmay Başkanlığı Kıbrıs Türk Barış Kuvvetleri Komutanlığı, a.g.e., s.186.

${ }^{60}$ Mütercimler, a.g.e., s.420.

${ }^{61}$ Ali Denizli, "Kıbrıs'ta Yunan Terör Örgütü EOKA ve Katliamları”, Uluslararası Eğitim ve Tarih Araştırmaları Dergisi, Y1l: 2, Sayı: 2, Haziran 2020, s.1-25.
} 
Meclisi Başkanı Glafkos Klerides başkan olurken Yunanistan'da da Konstantin Karamanlis sivil bir idare kurmuştur. Ateşkes ilanıyla birlikte Türkiye, Yunanistan ve İngiltere Dişişleri Bakanları 25 Temmuz 1974 tarihinde toplanmış ve bu süreç sonunda Birinci Cenevre Konferansı Çalışmaları başlamıştır. Yapılan görüşmelerden sonra 30 Temmuz 1974 tarihinde kabul edilen bir metin üzerinde anlaşmaya varılmıştır. ${ }^{62} \mathrm{Bu}$ metne Cenevre Deklarasyonu denilmiştir. Cenevre Deklarosyonu kapsaminda; "Ada'da bir güvenlik bölgesinin kurulması, Rum ve Yunan işgalindeki Türk bölgelerinin derhal boşaltılması, tutsak durumunda olan asker ve sivil personelin derhal mübadele edilmeleri veya serbest bırakılmaları kararlaştırılmıştır. Ayrıca, Ada'da barışın sağlanması, Anayasaya uygun bir hükümetin tekrar kurulması, Kıbrıs Cumhuriyeti'nde Kıbrıs Türk toplumu ve Kıbrıs Rum Toplumu olmak üzere iki otonom idarenin mevcudiyetinin kabul edilmesi" kabul ve ilan edilmiştir. ${ }^{63}$ Cenevre Deklarasyonu ile iki ayrı özerk idarenin kabul edilmiş olması, Kıbrıs Rumlarının Türk Toplumunu temsil etmediğini göstermiştir. ${ }^{64}$

Kıbrıs'ta barışın sağlanması ve anayasal düzenin yeniden tesisi amacıyla yapılan Birinci Cenevre Konferansı, Yunanistan ve Kıbrıs Rus tarafinın tutumu sebebiyle uygulanamamıştır. Özellikle Yunanistan ve Kıbrıs Rum Kesimi'nin 30 Temmuz 1974 tarihli Cenevre Antlaşması ile üstlendikleri yükümlülükleri yerine getirmemeleri bu durumun ana sebebini teşkil etmiştir. Adada ateşkesin ihlal edilmesi, çatışmaların önlenmesi amacıyla kabul edilen güvenlik bölgesinin saptanmasına yanaşılmaması, işgal altındaki Türk köylerinin boşaltılmaması ve esirlerin serbest bırakılmaması bu durumun en önemli göstergeleri olmuştur.

Gelişmeler bu çerçevede iken 30 Temmuz 1974 tarihli Birinci Cenevre Antlaşması'nda kararlaştırıldığı gibi 8 Ağustos 1974 tarihinde Cenevre'de bulunan Uluslar Sarayında İkinci Konferans başlamıştır. Konferansa; Türkiye Dışişleri Bakanı Turan Güneş, Yunanistan Dışişleri Bakanı Yorgo Mavros ve İngiltere Dışişleri Bakanı James Callaghan katılmıştır. Daha sonra 10 Ağustos 1974 tarihi itibarıyla görüşmelere Kıbrıs Türkleri adına Rauf Denktaş, Kıbrıs Rumları adına da Glafkos Klerides dâhil olmuştur. ${ }^{65}$

İkinci Cenevre görüşmelerinin 10 Ağustos 1974 tarihindeki görüşmeleri sırasında söz alan Rum Kesimi temsilcisi Glafkos Klerides, "1960'a dönelim" teklifinde bulunmuştur. Bu teklif Yunanistan tarafından da desteklenmiştir. Bu

62 Güner Göktuğ, Kuzey Kıbrıs Türk Cumhuriyeti'ni Hazırlayan Siyasi Nedenler, İstanbul Üniversitesi Sosyal Bilimler Enstitüsü Yayınları, İstanbul, 1990, s.116-117.

${ }^{63}$ Resmi Gazete, Kıbrıs Türk Federe Devleti, Sayı 71, Ek IV, Karar Numarası:1, 11 Kasım1976; Aykut Edibali, Türkiye'nin Kıbrıs Politikası Nasıl Olmalıdır?, Otağ Yayınları, Ankara, 1974, s.60-65.

${ }^{64}$ Cerrahoğlu, a.g.e., s.36.

${ }^{65}$ Cumhuriyet Gazetesi, 11 Ağustos 1974, s.1. 
sırada İngiltere Dışişleri bakanı James Callaghan da 16 Ağustos 1960 tarihinde yürürlüğe giren Kıbrıs Cumhuriyeti Anayasası'nın devam ettirilmesinden yana tavır ve tutum almıştır. ${ }^{66}$

Kıbrıs Türk temsilcisi Rauf Denktaş, Glafkos Klerides'in önerisine karşı çıkarak 1960 anayasasına dönülemeyeceğini açıklamıştır. Kıbrıs'taki Türk toplumunu koruyamayan bir anayasanın kâğıttan ibaret olduğunu açıklamıştır. Bu yüzden Denktaş, coğrafi esasa dayanan, güvenlik içinde yaşanılabilecek bir taksim teklifinde bulunmuştur. Yunanistan Dişişleri Bakanı Yorgo Mavros ve Kıbrıs Rum temsilcisi Glafkos Klerides bu teklife karşı çıkarak, uzlaşmaz bir tavır sergilemeye başlamıştır. Yunanistan ve Kıbrıs Rum kesimi bu tavırları ile Türk toplumunun haklarını gözetecek bir anlaşmaya yanaşmamıştır. Amaçları zaman kazanmak, meseleyi diplomasinin dolambaçlı yollarına sokmak ve milletlerarası baskıyla yeniden eski durumu tesis etmek olarak belirmiştir. İngiltere Dışişleri Bakanı James Callaghan da Yunanistan ve Kıbrıs Rum Kesimi temsilcilerinin tutumlarına göz yummuştur. Bu durum görüşmelerden bir sonuç alınmasını engellemiştir. Görüşmeler devam ederken Kıbrıs'taki Türk birliklerinin etrafı hızlı bir şekilde Rum askerleri tarafından sarılmaya başlamıştır. ${ }^{67}$ Neticede Yunan ve Rum ikilisinin anayasa düzeni konusunda kesin bir tavır almaktan kaçınıp oyalama taktiği izlemeleri ve adada Türklere yönelik saldırıların devam etmesi üzerine İkinci Cenevre Konferansı 14 Ağustos sabahının ilk saatlerinde Türk heyeti tarafından kesilmiştir. ${ }^{68}$

Bu sırada Türkiye Dışişleri Bakanı Turan Güneş, özel telefon hattından Başbakan Bülent Ecevit'i arayarak İkinci Barış Harekâtını başlatacak parolayı iletmiştir. Bu parola "Ayşe artık tatile çıkabilir." olmuştur. ${ }^{69}$

\section{3. İkinci Harekâtın Başlaması ve Gelişmeler}

Cenevre Görüşmelerinin sonuçsuz kalmasının ardından 14 Ağustos 1974 sabahı Kıbrıs'taki Türk birlikleri ikinci harekâta başlamıştır. Birinci Kıbrıs Barış Harekâtını sona erdiren ateşkesle Türkiye Kıbrıs'a 40.000 kişilik bir kuvvet yığmaya ve 300 tank göndermeye başarmıştır. Denizdeki donanma ve Türkiye'deki Hava Kuvvetleri de uyarılmıştır. Yalnız Kıbrıs'la değil, Türkiye'deki diğer birliklerde olası Türk-Yunan savaşı için aynı zamanda alarma geçirilmiştir. Ayrıca Türkiye Hükümeti, Birinci Cenevre Konferansı'nda alınan tüm kararlara uyulmadığını belirterek; "Türkiye, Kıbrıs Devletinin varlığının, bağımsızlı̆̆ının ve toprak bütünlüğ̈̈nün bir daha hiçbir şekilde tehdit

\footnotetext{
${ }^{66}$ Rauf Denktaş, Kıbrıs Girit Olmasın, Remzi Kitabevi, İstanbul, 2004, s.390-391.

${ }^{67}$ Hayrettin Erkmen, Süreyya Yüksel, H.Fahir Alaçam ve Diğerleri, Kıbrıs Sorunu Gelişmeler ve Görüşler, Sisav Yayınları, İstanbul, 1990, s.33.

${ }^{68}$ Armaoğlu, a.g.e., s.805.

${ }^{69}$ Oran, a.g.e., s.747-748.
} 
edilmeyeceğini ve Türk Toplumunun haklarının ve güvenliğinin tek başına sağlamak zorunda kalmıştır." diyerek harekâtın gerekçelerini açıklamıştır. ${ }^{70}$

14 Ağustos 1974 sabahı harekât öncesinde önce 05.40 itibarıyla denizden Rum Milli Muhafız Ordusu mevzileri bombalanmıştır. Ardından 06.00 ile 06.25 saatleri arasında Türk savaş uçakları tarafından Rum mevzileri vurulmuştur. ${ }^{71}$

Türkiye'den gönderilen kuvvetlerle Tümgeneral Bedrettin Demirel'in emrindeki 39'uncu Piyade Tümeni ve Tümgeneral Fazıl Polat'in emrindeki 28'inci Piyade Tümeni Girne kıyısından Magosa'ya doğru ilerlemiştir. 39'uncu Piyade Tümeni Karatepe, Minareliköy ve Serdarlı'yı ele geçirmiştir. 28'inci Piyade Tümeni de Timbu Havaalanı, Kırklarköy ve Paşaköy’ü almıştır. Girne kıyısında bulunan Çakmak Özel Görev Kuvveti de Arapköy, Gözübüyük ve Esentepe'yi ele geçirmiştir. Bu sırada Rum Milli Muhafız Ordusu, Türk birliklerinin uzağında kalan ve kuşatma altında bulundurdukları Türk yerleşim bölgelerine saldırmıştır. Özellikle Magosa Kalesine sı̆̆ınmış olan sivil halka ve onları koruyan Magosa Sancağı Mücahitlerine şiddetli taarruzlarda bulunmuşlardır. Ancak yine de Magosa Sancağı Mücahitleri, durumları çok kritik bir hal almasına karşın mücadelelerine devam etmiştir. Bu sırada 39 ve 28'inci Piyade Tümenlerinin güney yanını koruyan Kıbrıs Türk Alayı, düz ovada bulunduğundan Yunan Alayının yoğun bir ateşine maruz kalmıştır. Buna saldırılara rağmen Kıbrıs Türk Alayı, Yunan Alayını güneybatıdan kuşatmayı başarmıştır. ${ }^{72}$ Ancak Grammer School Tepe inatla Yunan Alayınca savunulmuştur. Bunun üzerine iki jet uçağı Kıbrıs Türk Alayı'nın desteğine verilmiştir. Böylece Yunan Alayı Komuta üssü olarak kullanılan Grammer School Türk uçaklarının desteğiyle ele geçirilmiştir. Yunan Alayı ağır bir yenilgiye uğramış, Alay Sancağının içinde bulunduğu birçok silah ve gereç Türk birliklerinin eline geçmiştir. ${ }^{73}$

15 Ağustos 1974 tarihinde 39'uncu Piyade Tümeni, Rum Milli Muhafız kuvvetlerinin bulunduğu Magosa'nın kuzeyindeki Boğaz'ı ele geçirmiştir. Bu sırada 28'inci Piyade Tümeni de Magosa'yı ele geçirmiş, ardından Maraş kurtarılmıştır. Magosa'nın ele geçirilmesi ile şehrin kalesine sığınmış 12.000 Kıbrıslı Türk kurtarılmıştır. Aynı dönemde Komando Tugayı Güzelyurt istikametinde taarruza başlamıştır. Ancak, tankların bir kısmının Rum Milli

\footnotetext{
${ }^{70}$ Ahmet Aydoğdu, Kıbrıs Sorunu Çözüm Arayışlar "Annan Planı ve Referandum Süreci, BRC Basım ve Matbaacilık, Ankara 2005, s.45.

${ }^{71}$ Sami Çalık, Kıbrıs Barış Harekâtında Hava İndirme Birlikleri ve Hava İndirme Harekâtı, Erciyes Üniversitesi Sosyal Bilimler Enstitüsü Tarih Ana Bilim Dalı Yayımlanmamış Yüksek Lisans Tezi, Kayseri, 2006, s.125-126.

${ }^{72}$ Erik Jan Zürcher, Modernleşen Türkiye'nin Tarihi, İletişim Yayınları, İstanbul, 2008, s.401.

${ }^{73}$ Armaoğlu, a.g.e., s.805-806.
} 
Muhafız Ordusu kuvvetleri tarafından hazırlanmış olan mayın tarlasına düşmesi üzerine taarruz durdurulmuştur. ${ }^{74}$

16 Ağustos 1974 39’uncu Piyade Tümeni, Karpas Yarımadasını güvenlik altına alırken, 28'inci Piyade Tümeni de Magosa çevresinin emniyetini sağlamıştır. Komando Tugayı ise mayın tarlasının temizlenmesinden sonra yeniden taarruza başlamıştır. Hızla ilerleyen Komando Tugayı; Güzelyurt, Lefke ve Yeşilırmak' 1 ele geçirmiştir. ${ }^{75}$

İkinci Barış Harekâtı 16 Ağustos 1974 akşamı saat 19.00'dan itibaren Türkiye'nin Birleşmiş Milletler Güvenlik Konseyi'nin aynı günlü kararına uyarak ateşkesi kabul etmesiyle sona ermiştir. İki gün içinde Türk Ordusu, Magosa, Lefkoşa ve Kokkina çizgisine ulaşarak adanın \%38'ini kontrolüne altına almış ve adadaki Türkler için güvenli bir bölge oluşturmuştur. ${ }^{76}$

İkinci Kıbrıs Hava Harekâtı sırasında Türk Hava Kuvvetleri birliklerinden; 171'inci Filo tarafından 29 görev kapsamında 70 sorti, 172'nci Filo tarafından 29 görev kapsamında 47 sorti, 81'inci Filo tarafından 18 görev kapsamında 46 sorti ve 184'üncü Filo tarafından keşif görevi kapsamında 34 sorti olmak üzere toplam 197 sorti icra etmiştir. ${ }^{77}$

\section{Sonuç}

Kıbris Adası, 1877-1878 Osmanl1-Rus Harbi sonrasında imza edilen Ayastefanos Antlaşmasının değiştirilmesi karşılığında İngiltere'nin vereceği desteğe istinaden belli şartlar altında bu ülkeye bırakılmıştır. Neticede İngiltere'nin desteği ile Ayastefanos Antlaşması yerine Berlin Antlaşması imza edilmiş ve Rusların sıcak denizlere inmesinin önüne geçilmiştir. İngiltere, Kıbrıs Adası'nı alarak uzak doğudaki sömürgelerine giden yol üzerinde önemli bir üsse sahip olmuştur. Birinci Dünya Savaşı başlayınca İngiltere, Osmanlı Devleti'nin İttifak Grubu'nda yer almasından dolayı Ada'yı ilhak ettiğini açıklamıştır. Lozan Antlaşması ile yeni kurulan Türkiye Devleti, bu defacto durumu yani Kıbrıs'in İngiltere'nin mülkü olduğunu kabul etmiştir. İkinci Dünya Savaşı sonunda İngiltere Ortadoğu'daki gücünü bölgeden çekerken, Ada'daki etkinliğini sınırlamak istemiştir. Bu durumdan yararlanmak isteyen Rumların, Ada'yı Yunanistan'a bağlamak istemesi olayların fitilini ateşlemiştir. Türkiye bu gelişmeler karşısında, adadaki soydaşlarını korumak için soruna ilgi göstermeye başlamış ve herhangi bir oldubittiyi kabul etmeyeceğini açıklamıştır.

\footnotetext{
${ }^{74}$ Koç, a.g.e., s.75.

75 Toluner, a.g.e., s.207-210.

76 Öztürk, a.g.e., s.40.

77 Özdemir, a.g.m., s.499.
} 
1960'lı yılların başından itibaren Ada'da birçok şiddet olayı yaşanmış ve bunun sonucunda Türkler katliama maruz kalmıştır. Türkiye, olaylar karşısında kademeli bir tepki göstermiş ve bu sırada hava gücünün caydırıcılığını adadaki sükûnetin sağlanmasında kullanmıştır. Bu kapsamda 1963, 1964, 1967 ve 1974 yıllarında Türk Hava Kuvvetleri tarafından harekâtlar gerçekleştirilmiş ve Ada'da yaşayan Türk toplumunun hak ve menfaati ile varlıklarının korunmasına katkı sağlanmıştır.

1974 yılında düzenlenen iki harekât ile bölgede barışın günümüze kadar sürmesinin temelleri atılmıştır. Birinci ve İkinci Barış harekâtı kapsamında; Türk Ordusu 35 subay, 41 astsubay, 421 erbaş ve er ile 1 sivil işçi olmak üzere toplam 498 şehit verirken, Kıbrıs Türk toplumu da 70'i mücahit olmak üzere 340 şehit ve 1.200 civarında yaralı vermiştir. Yunanistan ve Rum Kesimi ise 4.000 ölü ve 12.000 yaralı vermiştir. Savaş dışında olmasına rağmen Birleşmiş Milletler Barış Gücü'nden 3 Avusturyalı asker ölmüş, 24 Avustralyalı, 17 Finlandiyalı, 4 İngiliz ve 3 Kanadalı asker yaralanmıştır. Bu harekât kapsamında Türk Hava Kuvvetlerinden beş personel şehit olmuştur. ${ }^{78}$

1974 Kıbrıs Hava Harekâtı boyunca Türk Hava Kuvvetleri birlikleri tarafından; yakın hava desteği, hava indirme, keşif, tecrit, himaye ve taarruz harekâtları kapsamında toplam 930 sorti gerçekleştirilmiştir. ${ }^{79}$ Böylece Türk Hava kuvvetleri harekât ile Kıbrıs'taki Türk varlığının korunmasında ve Ada'daki Türk varlığının devamında önemli bir rol üstlenmiştir.

\footnotetext{
${ }^{78}$ Deniz Kurt, Yavuz Pehlivan, Erdal Korkmaz, Kuruluşundan Günümüze Türk Hava Kuvvetleri Harekât ve Teşkilatlanma Tarihi (1952-2020), Cilt III, Ankara, 2020, s.142.

${ }^{79}$ Özdemir, "1974 Kıbrıs Barış Harekâtı Kapsamında Türk Hava Kuvvetleri Tarafından İ́cra Edilen Hava Harekâtı ve Görevleri Üzerine Bir Değerlendirme", s.502; Başka bir kaynakta 1974 yılında gerçekleştirilen toplam sorti sayısı 1030 olarak verilmiştir. Ayrıntılı bilgi için Bkz. Kurt vd., s.141-142.
} 


\section{Kaynaklar}

Apuhan, Ferhat. 1974 Kıbrıs Barış Harekâtı ve Bingöllü Kıbrıs Gazileri, Yüzüncü Yıl Üniversitesi Sosyal Bilimler Enstitüsü, Yayımlanmamış Yüksek Lisans Tezi, Van, 2017.

Armaoğlu, Fahir. 20.Yüzyıl Siyasi Tarihi, c.1, İstanbul, Türkiye İş Bankası Kültür Yayınları, 1992.

Atasever, Müge. Kıbrıs Sorununun Tarihi Gelişimi, Dokuz Eylül Üniversitesi Hukuk Fakültesi Dergisi, Cilt: 12, Özel S., 2010, s.1487-1530 (Basım Y11: 2012).

Artuç, İbrahim, Kıbrıs'ta Savaş ve Barış, İstanbul, Kastaş Yayınları, Eylül 1989.

Atun, Ali Fikret. Avrupa Birliği ve Kıbrss'ın Avrupa Birliğine Üyeliği, Lefkoşa, Kıbrıs Türk Mücahitler Derneği Yayınları, 2001.

Atun, Ali Fikret. İkinci Kıbris Seferi 20 Temmuz 1974, İstanbul, Harp Akademileri Basımevi, 1999.

Aydoğdu, Ahmet, Kıbrıs Sorunu Çözüm Arayışları "Annan Planı ve Referandum Süreci, Ankara, BRC Basım ve Matbaacılık, 2005.

Baday, Gökhan. 1974 Kıbrıs Barış Harekâtı ve Kars-Ardahan Kıbrıs Şehitleri İe Gazileri, Yayımlanmamış Yüksek Lisans Tezi, Kafkas Üniversitesi Sosyal Bilimler Enstitüsü, Kars 2009.

Başbakanlık Devlet Arşivleri Genel Müdürlüğü. Osmanlı İdaresinde Kıbrıs (Nüfusu, Arazi Dağılımı ve Türk Vakıflar), Ankara, 2000.

BCA. 030.01/16.89.10, 30 Kasim 1967.

Bayülken, Ümit Halûk. "The Cyprus Question and the United Nations," Foreign Policy (Dış Politika), Vol.4, No.2-3 (1974).

Cerrahoğlu, Zehra Yalçınkaya. Birleşmiş Milletler Gözetiminde Kıbrıs Sorunu ile İlgili Olarak Yapılan Toplumlararası Görüşmeler 1968-1990,T.C. Kültür Bakanlığı Yayınları/2061, Ankara, 1998.

Coşkun, Yasin. “Kıbrıs Sorunu Üzerindeki Türk-Yunan Diyaloğunun Başarısızlığı (1966-67) ve İngiliz Politikası", Karatekin Edebiyat Fakültesi Dergisi, 4/1, Çankırı, 2014.

Cumhuriyet Gazetesi. 11 Ağustos 1974.

Çakmak, Büşra. “Kıbrıs'ta İngiliz Yönetimi ve Yapılan Çözüm Planları”, Tarihte Kıbrıs II, Editör: Osman Köse, Akdeniz Karpaz Üniversitesi, İstanbul, 2017. 
Çalık, Sami. Kıbrıs Barış Harekâtında Hava İndirme Birlikleri ve Hava İndirme Harekâtı, Erciyes Üniversitesi Sosyal Bilimler Enstitüsü, Yayımlanmamış Yüksek Lisans Tezi, Kayseri, 2006.

Çay, Abdulhaluk. Kıbrıs'ta Kanlı Noel-1963, Türk Kültürü Araştırma Enstitüsü Yayınları, Ankara, 1989.

Denizli, Ali. “Kıbrıs'ta Kanlı Noel-1963 Yunan ve Rum İkilisince Türk Halkının Yok Edilmeye Çalışılması", Prof. Dr. Abdulhalûk Mehmet Çay 35. Yıl Armă̆an Kitabı, İksad Yayınevi, Ankara, 2020.

Denizli, Ali. "Kıbrıs'ta Yunan Terör Örgütü EOKA ve Katliamları", Uluslararası Eğitim ve Tarih Araştırmaları Dergisi, Yıl: 2, S: 2, Haziran 2020, s.1-25.

Denktaş, Rauf. The Cyprus Triangle, K.Rustem\&Brother/George Allen\&Unwin, London, 1982.

Denktaş, Rauf. Kıbrıs Girit Olmasın, İstanbul, Remzi Kitabevi, 2004.

Dışişleri Belleteni. S.38, Kasım 1967.

Erdem, Turan. Kıbrıs Barış Harekâtında 3'üncü Paraşüt Taburu, Genelkurmay ATASE Başkanlığı Yayınları, Ankara, Genelkurmay Basımevi, 1999.

Edibali, Aykut. Türkiye'nin Kıbrıs Politikası Nasıl Olmalıdır?, Otağ Yayınları, Ankara, 1974.

Erkmen, Hayrettin. Yüksel Süreyya, Alaçam H.Fahir ve Diğerleri, Kıbrıs Sorunu Gelişmeler ve Görüşler, İstanbul, Sisav Yayınları, 1990.

Eroğlu, Hamza. Kıbrıs Uyuşmazlığı ve Kıbrıs Barış Harekâtı, Ankara, 1975.

Ertekün, Necati Münir. The Cyprus Dispute, University Press, Oxford, 1981.

Evcil, Cumhur. Yavru Vatan Kıbrıs'ta Zaferin Hikâyesi, Ankara, Genelkurmay Askerî Tarih ve Stratejik Etüt Başkanlığı Yayınları, 1999.

Genelkurmay Başkanlığı Kıbrıs Türk Barış Kuvvetleri Komutanlığı, Sebep ve Sonuçlarıyla 1974 Kıbrıs Barış Harekâtı, Genelkurmay Başkanlığı Kıbrıs Türk Barış Kuvvetleri Komutanlığı Yayını, Özdilek Matbaası, Lefkoşa, 1996.

Göktuğ, Güner. Kuzey Kıbrıs Türk Cumhuriyeti'ni Hazırlayan Siyasi Nedenler, İstanbul Üniversitesi Sosyal Bilimler Enstitüsü Yayınları, İstanbul, 1990.

Güler, Yavuz. “Kuzey Kıbrıs Türk Cumhuriyeti'nin Kuruluşuna Kadar Kıbrıs Meselesi", Gazi Üniversitesi Kırşehir Eğitim Fakültesi Dergisi, Ankara, 2004, $5 / 1$. 
Günsev, Mesut. Şafak Vakti Kıbrıs'ta (20 Temmuz 1974), Kastaş Yayınları, İstanbul, 1999.

Güvenlik Kuvvetleri Dergisi. Say1: 18, Lefkoşa, 1989.

Hava Kuvvetleri Komutanlığı. Hava Şehitleri Albümü, Cilt III, Ankara, Hava Basımevi, 1999.

İsmail, Sabahattin. Kıbrıs Cumhuriyeti'nin Doğuşu ve Çöküşü ve KKTC'nin Kuruluşu (1960-1983), İstanbul, 1992.

İsmail, Sabahattin. 150 Soruda Kıbrıs Sorunu, İstanbul, 1998.

Kıralp, Şevki. “1967-1974 Döneminde Kıbrıs Sorunu ve Türkiye ile Yunanistan'ın Kibris Politikaları", Journal of History Culture and Art Research, $7(2)$, s.444-460.

Koç, Süleyman. Dünden Bugüne Kıbrıs Sorunu ve Stratejik Yaklaşımlar, İstanbul, IQ Kültür Sanat Yayıncılık, 2005.

Kurt, Deniz, Pehlivan Yavuz, Korkmaz Erdal. Kuruluşundan Günümüze Türk Hava Kuvvetleri Harekât ve Teşkilatlanma Tarihi (1952-2020), Cilt III, Ankara, 2020.

Fırat, Melek. "1945-1960 Yunanistan'la İlişkiler,” Baskın Oran (ed.), Türk Dış Politikası, Kurtuluş Savaşından Bugüne Olgular, Belgeler, Yorumlar, cilt I, 8. Baskı, İstanbul, İletişim Yayınları, 2003.

Mütercimler, Erol. Bilinmeyen Yönleriyle Kıbrıs Barış Harekâtı, İstanbul, Arba Yayınları, 1998.

Mütercimler, Erol. Kıbrıs Barış Harekâtının Bilinmeyen Yönleri: Satılık Ada Kıbrıs, İstanbul, Alfa Basım Yayım Dağıtım Tic.Ltd.Şti., 5. Baskı, 2007.

Oberling, Pierre. Bellapais'e Giden Yol, Çeviren: Mehmet Erdoğan, Genelkurmay Askerî Tarih ve Stratejik Etüt Başkanlığı Yayınları, Ankara, 1988.

Olgun, Kenan - Balıkçığlu, Emrah. “The Times Gazetesi'ne Göre İngiliz Dönemindeki Kıbrıs'ta İdari Islahat", Uluslararası Insan Bilimleri Dergisi, Cilt: 9, Say1: 1, 2012, s.816-844.

Oran, Baskın. Türk Dış Politikası, İstanbul, İletişim Yayınları, 2001.

Özdemir, Atasay. “1974 Kıbrıs Barış Harekâtı Kapsamında Türk Hava Kuvvetleri Tarafından İcra Edilen Hava Harekâtı ve Görevleri Üzerine Bir Değerlendirme", Türk Hava Kuvvetlerinin 100'üncü Yılı Uluslararası Tarih Sempozyumu, Ayrıntı Basımevi, Ankara, 2013.

Öztürk, Osman Metin. Stratejik açıdan Doğu Akdeniz ve Kıbrıs, Ankara, Altınküre Yayınları, 2003. 
Serter, Vehbi Zeki. 'Kıbrıs' ta 15 Temmuz 1974' te Düzenlenen RumYunan Askeri Darbesi ve Mutlu Türk Barış Harekâtı'nın Başlaması (20 Temmuz 1974)", Türk-Yunan İlişkileri Bildirileri, Üçüncü Askeri Tarih Semineri, Genelkurmay Basımevi, Ankara, 1986.

Tandoğan, M. Şükrü. Kıbrıs Barış Harekâtı Birlikler ve Muharebeler, Türkiye Muharip Gaziler Derneği, Ankara, Türmantsan Organize Maatbacılık, 2015.

Tarakçı, Mustafa. Kıbrıs Barış Harekâtı, Hiperlink Yayınları, İstanbul, 2010.

Tarakçı, Mustafa. Kıbrıs Barış Harekâtı, Yayınlanmış Doktora Tezi, Hacettepe Üniversitesi Atatürk İlkleri ve İnkılâp Tarihi Enstitüsü, Ankara, 1998.

Toluner, Sevim. Kıbrıs Uyuşmazlığı ve Milletlerarası Hukuk, İstanbul Üniversitesi Hukuk Fakültesi Yayınları, İstanbul, 1977.

Turan, Şerafettin. Türk Devrim Tarihi IV Çă̆daşlık Yolunda Yeni Türkiye (İkinci Bölüm), Bilgi Yayınevi, 1. Baskı, Ağustos 1999.

Turhan, Turgut. "Tarihsel Bakış Açısıyla Kıbrıs Türk Hukuk Sistemi”, Ankara Üniversitesi Hukuk Fakültesi Dergisi, Ankara-2008, C. 57, S. 2, s.253-286.

Uçarol, Rifat. Siyasi Tarih, İstanbul, Filiz Kitabevi, 2000.

Yeniasır Mustafa-Gökbulut Burak-Tamer İsmail. “Ahmet Gazioğlu'nun Kıbrıs'ta Aşk ve Savaş Adlı Romanına 1974 Kıbrıs Türk Barış Harekâtı'nın Yansıması", Selçuk Üniversitesi Edebiyat Fakültesi Dergisi, 2020; (43): 149-182.

Zurcher, Erik Jan. Modernleşen Türkiye'nin Tarihi, İstanbul, İletişim Yayınları, 2008. 